\title{
Development of Education and Its Impact on The Population Composition of The Tribal People of Birbhum District of West Bengal
}

\author{
Dr. Prasasti Ghosh \\ Associate Professor of Geography \\ Birbhum Mahavidyalaya, Suri-731204, Birbhum, West Bengal , INDIA
}

\begin{abstract}
The term 'Development' is a process by which a person or a community can enhance or maximise their potentiality to improve or change their world. Similarly education is considered as an important factor in the process of development because through education a person acquire knowledge and skills by which a person or a community become able to overcome the problems, the difficulties to modernize their lifestyle in a particular situation and cultural context. Tribe is a group of distinct community people, with distinct culture and folklore mainly settled in the marginal tract of forest, hills and other tract isolated from the main stream depending on their land for their livelihood, distinct culture. Because of primitiveness, shyness, territorial integrity and nonassimilation in nature they always remain outside of the main stream. India, the vast geographical area with diversified ecological and cultural and linguistic zones have given shelter to more than five hundred type of tribal community constituting 08 per cent of total population in 2011. Because of' Isolation Approach' (leave them untouched) of the ruling administration and the British ruler in pre independence period as result of this isolation they could not enjoy the fruit of development programmes .According to the history of education the level of development was very poor and the education was mainly informal and it purely demand based. As result of this they were less modernized and culture was very poor. In spite of that their demographic composition was not so backward than other community people in spite of poor literacy rate as sex ratio in 1961 was in west Bengal was 874 and in Birbhum it is 1001 and it increases to 999 in West Bengal and 1024 in Birbhum in 2011.. The British ruler invited the Christian Missionaries for their welfare and to convert them into Christianity by which they can run administration smoothly. In post-independence period. To get an idea about the changes Tribal people of Birbhum district of West Bengal have taken for study. This district is situated in the western part of Santal Pargana Districts.
\end{abstract}

Keywords: Ecological, Cultural, Civilization, Sex Ratio, Demography.

\section{INTRODUCTION}

The largest concentration of tribal people anywhere in the world after Africa is India. According to 1951 census tribal people share 05.30 per cent (19147054) to total population. After the modification of Scheduled Tribes Lists it increases to 06.23 per cent (22511854) in 1956. This increase of 34 lakhs is due to the inclusion of some group. But the problem is that there is no satisfactory definition about tribe in the constitution. Tribes are "the tribes or the tribal communities or parts of groups within tribes or tribal communities" which the President may specify by public notification (Article 342).As these groups are presumed to form the oldest ethnological part of the population, and the term 'Adivasi' (Adi means original and vasi means inhabitant) has become current among certain people. The International Labour Organization has classified them as indigenous .[1] The characteristics by which the tribal people peoples are identified as a)primitiveness, b)distinct culture, folklore, belief system; 
c)geographical isolation and d)shyness to contact with other castes ,e Jbackward economy and their economy is based on subsistence level where there is no concept of surplus, self sufficient economy and economy depends upon barter exchange. They are settled across the whole area of this country but they are settled across the whole area of this country but mostly in ecologically marginal areas of hills, forest and other places isolated from the main stream. India the democratic country and secular nation is committed to all the people (inhabitants) for their development and welfare and it become a great challenge to the govt to provide proper provision of social justice to the tribal people, the weakest and marginalised section of its population. The history of India reveals that the tribal people are coexisted with the general people and also with ruler since the beginning of Indian civilization. But there is little knowledge about the interactions of the rulers of that past era with the tribal and the action of the administrators taken for the development and welfare of these indigenous communities. They enjoyed very little of facilities granted by the royalty in pre-British era because of their remotest and inaccessible habitat. They are exploited by other people of higher castes in one hand and isolation approach of the ruler described as 'leave them untouched'. Practically they are deprived of many civic facilities and isolated from civilized way of living. Because before independence and before the introduction of missionary activity the type of education was informal and traditional and help then to acquire practical knowledge changing their traditional thought.[2] After independence the integrationist approach consists of two types of measures as i) protective, and ii) promotional was the brain child of the Prime Minister Jawaharlal Nehru. So the founding fathers of our constitution desired to secure justice, social, economic and political for all citizen. That thought that inequality in socio-economic system may result deprivation and disadvantages for the poor and weaker sections of the society. As result of this the directive principles in the form of Article 46 have taken to provide "the state shall promote with equal care the educational and economic interests of weaker sections of the people, and in particular of the Scheduled Caste and Scheduled Tribes and shall protect them from social injustice and all forms of exploitation". To facilitate the implementation of the above Directive Principles, the constitution of India provides for a number of safeguards for them.. [3] These safeguard are broadly grouped into five categories, and among these five three categories as some safeguards are taken for this study. The characteristics and structure of population are important in population studies. This study includes such aspects as literacy and educational attainment, age, sex, marital status, family structure, economic status, language and religion. Among these age and sex are culturally or biologically assigned while other aspects are may be acquired by a person (Clarke)[.4 ]In this context, demographic composition makes an interesting study because it gives an idea about the trend of fertility, mortality and migration in recent trend.

\section{OBJECTIVE AND METHODOLOGY}

This study has taken to give a detail idea about the demographic composition of the tribal people of the state West Bengal and specially the district of Birbhum (moderately developed area). The major objective of this to give an idea about the demographic composition of the tribal people of Birbhum district of West Bengal and find out the changes in the demographic composition of this people as influenced by the larger society in the midst of which they still maintain this identity specially in socio-cultural and demographic terms. Demographic composition include the Age, Sex, Marital Status, Religion and the Literacy and Educational attainment ,most vital aspect in bringing changes in lifestyle. The tribal people of Birbhum district of West Bengal have taken for this study. In this study some aspects as education, age, sex ratio, and marital status have taken for study. The tribal people of this district share 6.74 per cent of total population. Birbhum district is located between $23^{\circ} 32^{\prime} 30^{\prime \prime}$ and $24^{\circ} 35^{\prime} 00^{\prime \prime}$ North latitude and $88^{\circ} 01^{\prime} 40^{\prime \prime}$ and $87^{\circ} 05^{\prime} 25^{\prime \prime}$ East Longitude. This district is situated in the eastern side of the Santal Pargana district (Map).This study based on I)field investigation 
(primary data) and secondary information and data; II)processing of data for analysis ; and iii)preparation of table, map and diagrams for interpretation.

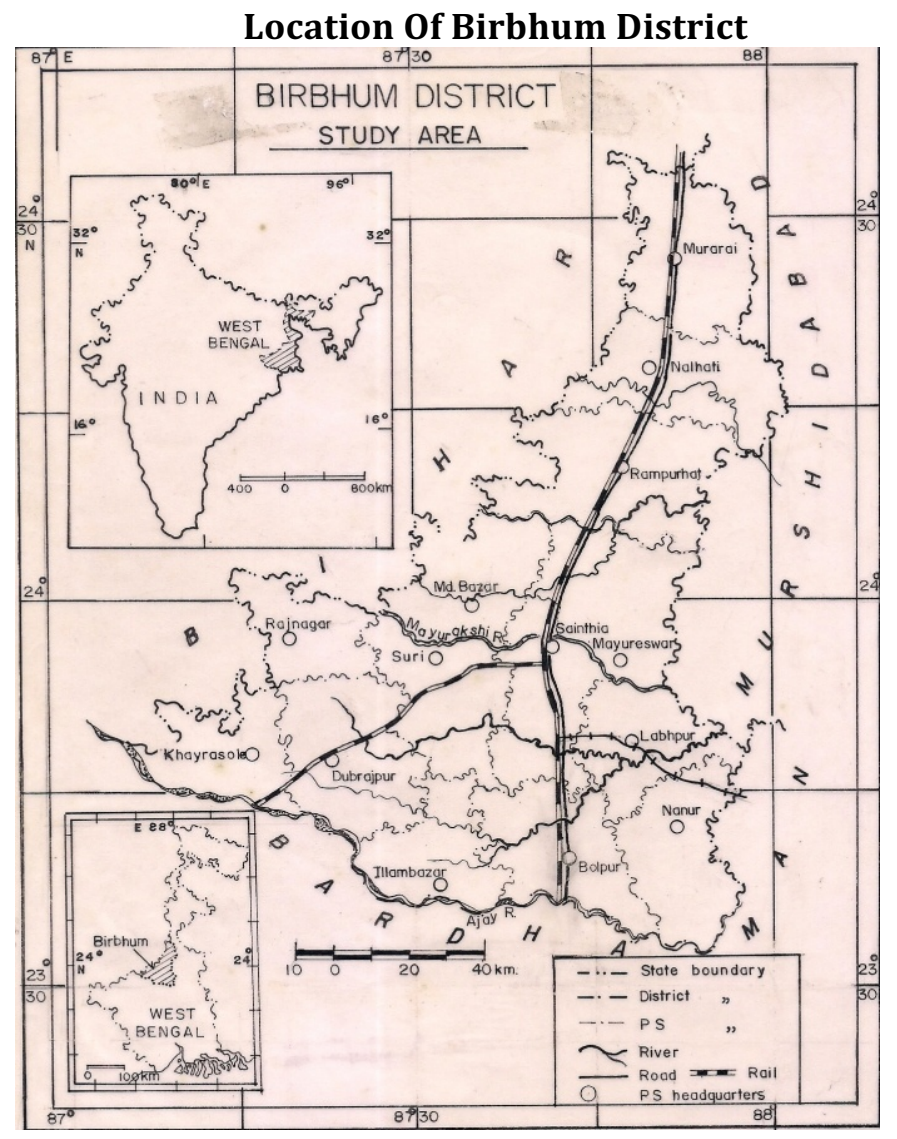

\section{Educational Attainment and Literacy}

Educational attainment is the most important among the qualities of a population (Trewartha).5 Education is an important input for human resource development . Level of literacy and educational attainment are not only important in socio-economic development but also help in eradication of poverty of any community. Education is more important to a person. It increase self- confidence and help in building the capacity to meet the challenges they faced for long period. Because of illiteracy and ignorance the tribal people are exploited and faced social oppression by middleman, traders, money lenders and other higher class people traditionally over the centuries. To mitigate the socio-economic exploitation and the social change classless, egalitarian, freedom to enjoy equal justice in every sphere of life education can play an important role. For the welfare, and social justice the Ministry of Welfare implements the following Central and Centrally sponsored schemes for educational development of ST students from Pre -Matric to Post-Matric and other through state govt. to reduce the gap in literacy between tribal and non-tribal people as i) Pre-Matric scholarship for children of those engaged in unclean occupation; ii) Post-Matric scholarship(100\%); iii) Book Banks; iv)scheme for girls hostel and boys hostel; v) Ashram school in Tribal Sub Plan areas; vi)Coaching and allied Scheme to provide textbooks stationeries , uniforms and mid-day meal ; and vii) National Overseas Scholarship (100\%).6 Beside this some vocational training are given on i)weaving ,ii)making of leather goods iii) carpentry , iv) sericulture etc. The National Policy on Education (NPE), Programme of Action (POA) committed the educational system to work for women's equality and empowerment. During late eighties these two schemes are modified and more priority is given to the education of women to equalise both the segment of the society to optimise the contribution of the female in socio-economic development. Special 
privileges in form of reservation of post in government services and seats in education institutions. For this number of beneficiaries is increasing gradually as shown below (table-01)

Table-01

Allotment And Beneficiaries In Different Educational Schemes (In \%) In Birbhum 1990-91, 2015-16

\begin{tabular}{|c|c|c|c|c|c|c|c|}
\hline & A & B & C & D & E & F & G \\
\hline $\begin{array}{c}1990-91 \\
(\mathrm{a})\end{array}$ & 8.53 & 50.67 & 0.06 & Nil & Nil & Nil & 8.90 \\
\hline $\begin{array}{c}1990-91 \\
(\mathrm{~b})\end{array}$ & 36.23 & 9.61 & 0.95 & Nil & Nil & Nil & Nil \\
\hline $\begin{array}{c}2015-16 \\
\text { (a) }\end{array}$ & 13.67 & 25.97 & 11.82 & 0.14 & 0.19 & 17.33 & 30.88 \\
\hline $\begin{array}{c}2015-16 \\
\text { (b) M }\end{array}$ & 54.23 & 21.98 & 6.11 & Nil & 0.15 & 4.89 & 12.65 \\
\hline $\begin{array}{c}2015-16 \\
\text { (b) F }\end{array}$ & 68.94 & 7.59 & 5.67 & 1.40 & 0.17 & 5.89 & 10.34 \\
\hline
\end{tabular}

Souece: Backward Classes Welfare Department, Suri, Birbhum

\section{ALLOTMENT(a) AND BENEFICIARIES(b) IN EDUCATIONA} SCHEMES(IN\%), BIRBHUM

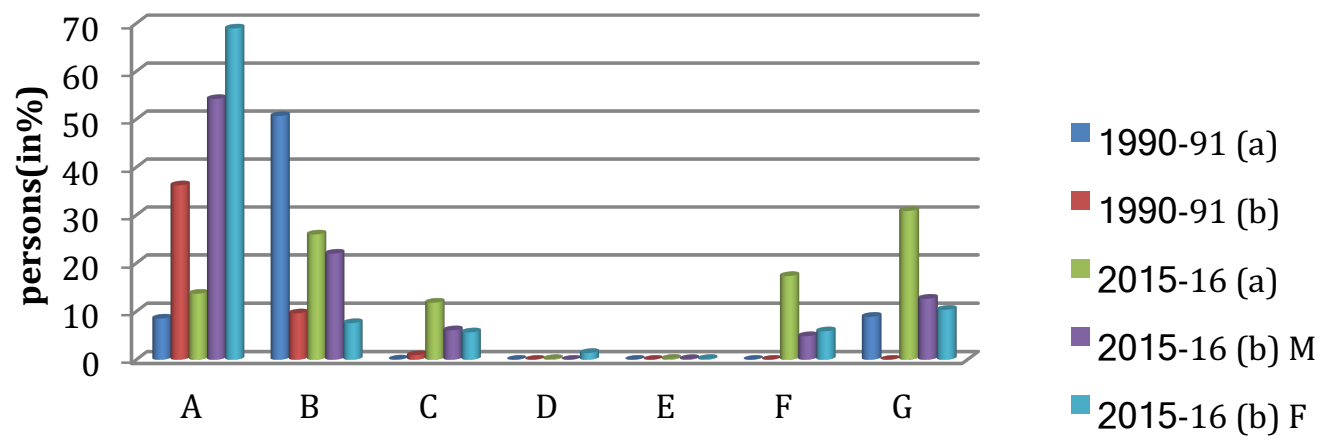

A=Book grant \& Exam.Fees, B= Hostel Charges, C=Ashram Hostel,D= Merit Scholaeship(v-x), E=Merit Scholarship(ix-xii),F= PMS

A=BOOK GRANTS \&EXAM. FEES; $B=$ HOSTEL CHARGE; C= ASHRAM HOSTEL; $D=$ CS PREMATRIC SCHOLARSHIP (IX-X); E=MERIT SCHOLARSHIP(V-X); F= MERIT SCHOLAESHIP (IXXII); G= POST MATRIC SCHOLARSHIP

\section{$\mathrm{a}=$ Allotment of Grant; $\mathrm{b}=$ Beneficiary $\mathrm{M}=\mathrm{MALE} ; \mathrm{F}=\mathrm{FEMALE}$}

The data on allotment and beneficiaries in different schemes shows that the tribal people specially females are more interested in getting education than males. In 1990-91 there was no beneficiary for Post Matric scholarship but in 2015-16 this scheme highest percentage of grant as 33.88 per cent. In 'Sikhasree' scheme which was named Book grants and exam fees in 199091 highest percentage of beneficiaries. Data on beneficiary (boys and girls) shows (Table-02) boys are enjoyed the schemes more than female. The most interesting thing is that in 1990-91 no of beneficiaries was nil but in 2015-16 percentage of boy and girl beneficiary be beneficiary become 12.65per cent and10.34 per cent. In both year number of beneficiary is highest than other scheme which indicate that these people become interested in education. The data about the number of boy and girl beneficiary shows the trend. 
Table-02

Boys And Girls (In NOS) Benefitted From Educational Schemes

\begin{tabular}{|l|l|l|l|l|}
\hline & $1989-1990$ & $1990-1991$ & $2014-2015$ & $2015-2016$ \\
\hline BOYS & 3365 & 3022 & 7003 & 5401 \\
\hline GIRLS & 2244 & 2014 & 4359 & 2292 \\
\hline
\end{tabular}

Source: ITDP Office, Suri, Birbhum.

\section{BOYS AND GIRLS BENIFITTED FROM EDUCATIONAL SCHEMES}

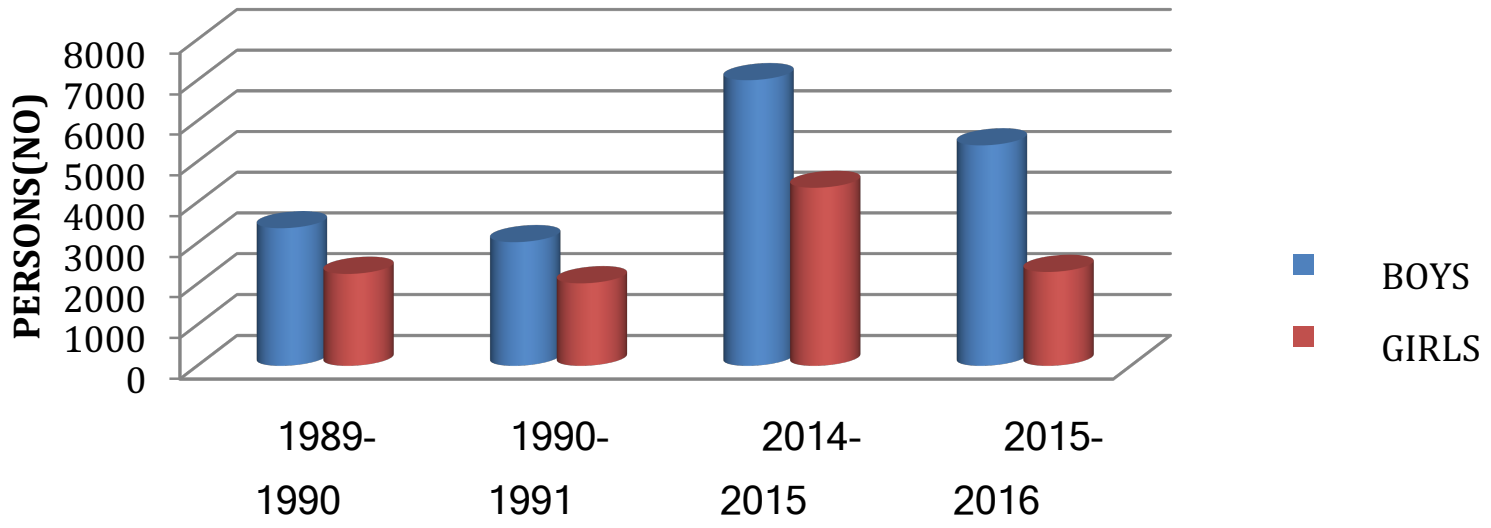

YEAR

This data and diagram shows that there is no uniform trend in increase the number of beneficiaries. Because of some factors they are always remain backward in literacy and educational backwardness .This factors are i) Geographical location of the settlement; ii) lack of schooling facilities; iii) lack of education of parents; iv) education system and medium of learning and v)high teacher-pupil ratio; vi) poverty. Most of the settlement of tribal community developed in that place which are isolated from main stream. Most of the school is situated in non-tribal areas. Number of primary school is more in number and among these very few are near to their locality. The secondary and higher secondary schools are few in number but all are out of their locality. The curriculum which is followed in the school is not so relevant to the life they lead and medium of instruction is Bengali which is also another reason for apparent apathy for education because the children can't understand this language. Above all the most important factor for backwardness is poverty. The poor economic condition let the parents feel no urge for educating their children. So the number of beneficiary is increasing satisfactorily. The literacy rate among the tribal people is increasing as the secondary data shows Table-3.

Table-03 Increase Of Literate Tribal Population (In \%), 1961-2011.

\begin{tabular}{|l|r|r|r|r|r|r|}
\hline & 1961 & 1971 & 1981 & 1991 & 2001 & 2011 \\
\hline INDIA & 08.54 & 11.30 & 16.35 & 29.60 & 47.1 & 59.0 \\
\hline $\begin{array}{l}\text { WEST } \\
\text { BENGAL }\end{array}$ & 06.55 & 08.92 & 13.21 & 27.78 & 43.4 & 57.3 \\
\hline BIRBHUM & 03.39 & 04.49 & 07.53 & 11.72 & 25.23 & 40.40 \\
\hline
\end{tabular}

Source: Census of India and west Bengal, Birbhum 1961-2011. 


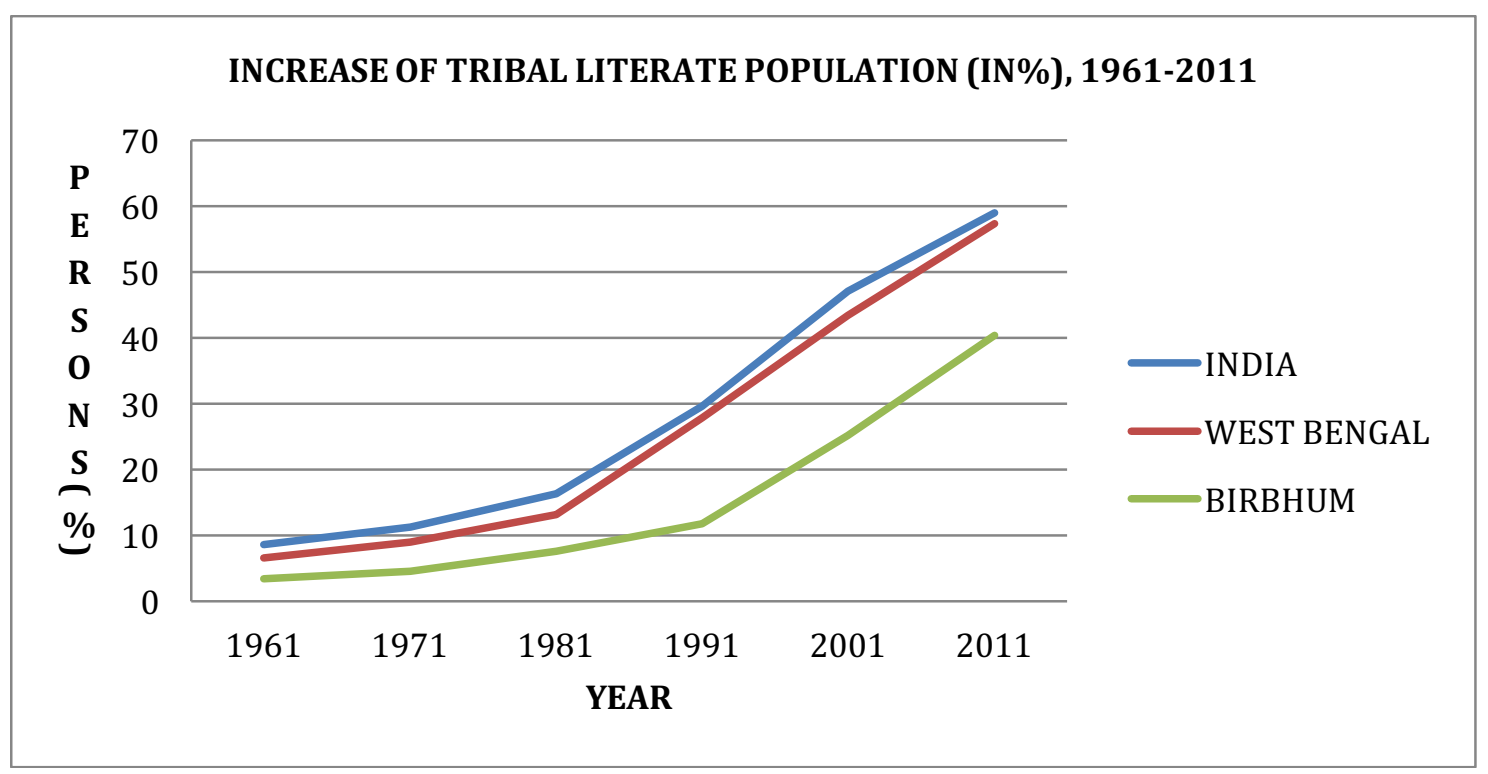

In 1961 percentage of literate population was 08.54. It increases to 59.0 per cent in 2011 . In West Bengal it was 06.55 per cent and increases to 57.3 per cent. In Birbhum district, the less developed area increase rate of tribal people is not bad as 03.39 per cent to 40.4 per cent. But this percentage of literacy among the tribal is not satisfactory in comparison to non-tribal people because of so many factors among them some are most important as i) non availability of school in locality ; ii)poor economic condition which create apathy in getting education in some cases; iii)curricula and medium of learning are important factor to discourage them in getting education.

Table -04A

Male And Female In Different Education Level In Birbhum (In \%) 1981, 2001** 2016

\begin{tabular}{|l|c|c|c|c|c|c|}
\hline & $\mathrm{A}$ & $\mathrm{B}$ & $\mathrm{C}$ & $\mathrm{D}$ & $\mathrm{E}$ & $\mathrm{F}$ \\
\hline MALE(1) & 87.28 & 06.33 & 04.51 & 01.75 & 0.07 & 0.04 \\
\hline FEMALE(1) & 97.75 & 01.43 & 0.60 & 0.21 & 0.009 & 0.01 \\
\hline MALE(2) & 64.16 & 01.82 & 20.60 & 5.68 & 0.37 & 0.27 \\
\hline FEMALE(2) & 75.24 & 0.83 & 15.50 & 08.29 & 0.09 & 0.05 \\
\hline MALE(3) & 47.77 & 03.22 & 17.24 & 23.66 & 06.14 & 01.97 \\
\hline FEMALE(3) & 65.28 & 03.71 & 11.43 & 15.27 & 03.10 & 01.21 \\
\hline
\end{tabular}

A= LITERATE WITHOUT EDUCATION LEVEL; B= PRIMARY+JUNIOR HIGH ; $\mathrm{C}=$ SECONDARY + HIGHER SECONDARY ; D=NON TECHNICAL DIPLOMA NOT EQUAL TO DEGREE ; $E=$ TECHNICAL DIPLOMA NOT EQUAL TO DEGREE ; F=UG, PG AND OTHER.

Source: Census of India, West Bengal Series, 1981, 2001 \& 2016 *Field Investigation 


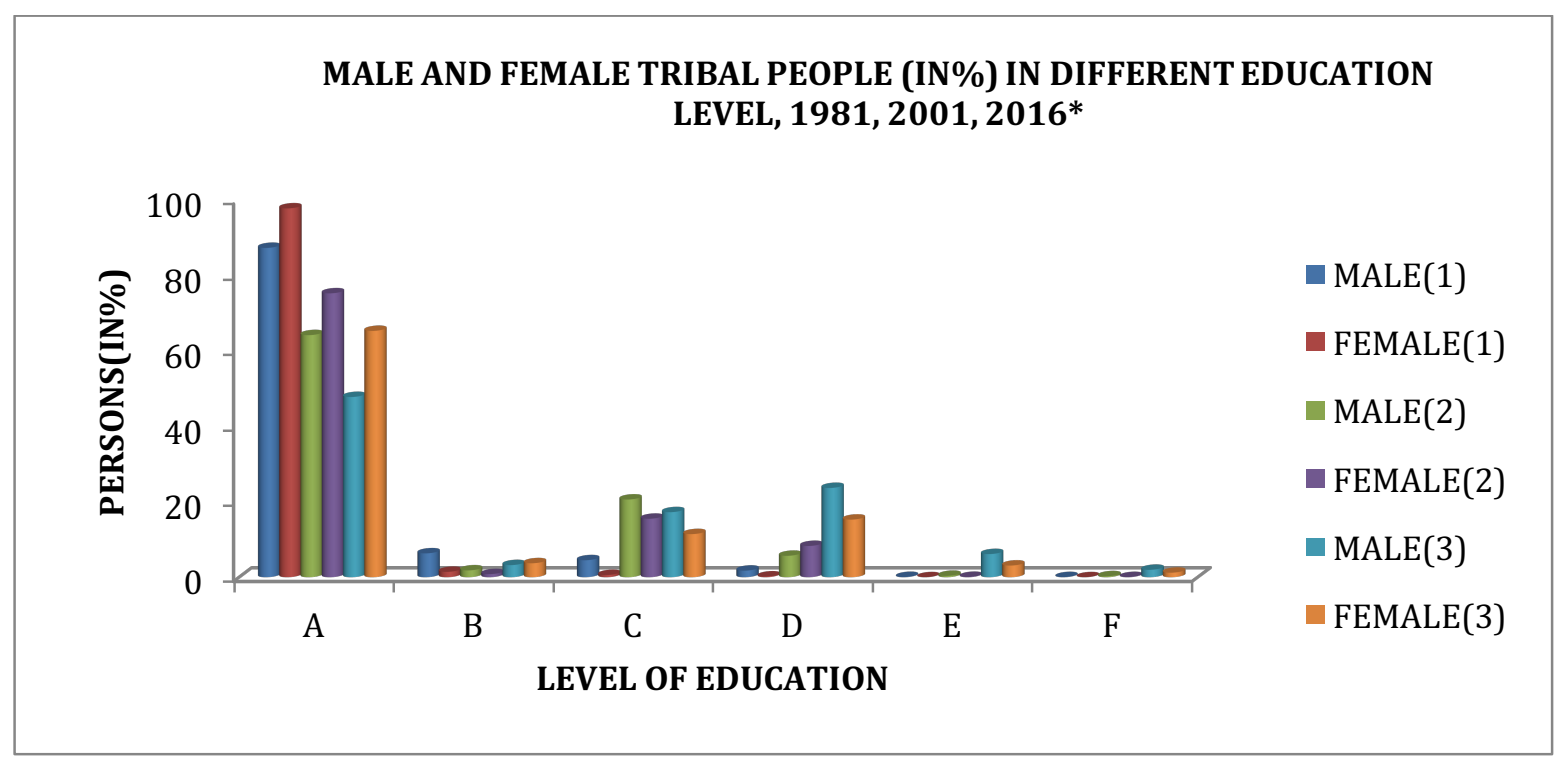

The data shows that percentage of illiterate male person is gradually decreasing as 87 per cent to 45 per cent in 2016. On the other hand literate population without educational level is increasing among both the male and female because major percentage of people are not so interested in formal education. Because they are hard working people so they do not want to spent time for education in one hand and on the other hand some factors (mentioned before) create apathy in taking education. As result of this literate population was poor in past decade as 87 per cent among male and 97 per cent among female but it gradually decreasing as the primary percentage of people are not so interested in formal education. Because they are hard working people so they do not want to spent time for education in one hand and data shows. In 1981 and 2016 percentage of male and female in primary and matriculation standard is go data shows. In 1981 and 2016 percentage of male and female in primary and matriculation standard is good. The tribal people

Table-4B: Male And Female Tribal People In Educational Institution (In \%) In Birbhum, 2001

\begin{tabular}{|l|l|l|l|l|l|}
\hline & School & Collee & $\begin{array}{l}\text { Vocatioal } \\
\text { institute }\end{array}$ & $\begin{array}{l}\text { Other } \\
\text { Institue }\end{array}$ & $\begin{array}{l}\text { Literacy } \\
\text { Centre }\end{array}$ \\
\hline Male & 94.91 & 1.15 & 0.19 & 0.20 & 2.26 \\
\hline Female & 97.81 & 0.37 & 0.21 & 0.09 & 1.53 \\
\hline
\end{tabular}

Source :Census of India, West Bengal Series, 2001.

of adult to old prefer to take education in literacy centre. But the youth people in the group of 0-14 years prefer to go school.upto the junior basic level as the data is concern. 


\section{MAL4E AND FEMALE(\%) IN EDUCATIONAL INSTITUTION IN BIRBHUM DISTRICT, 2001}

MALE

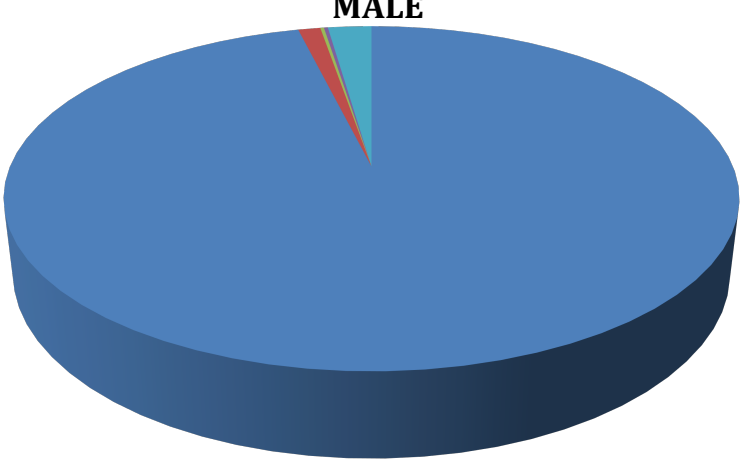

\section{Female}

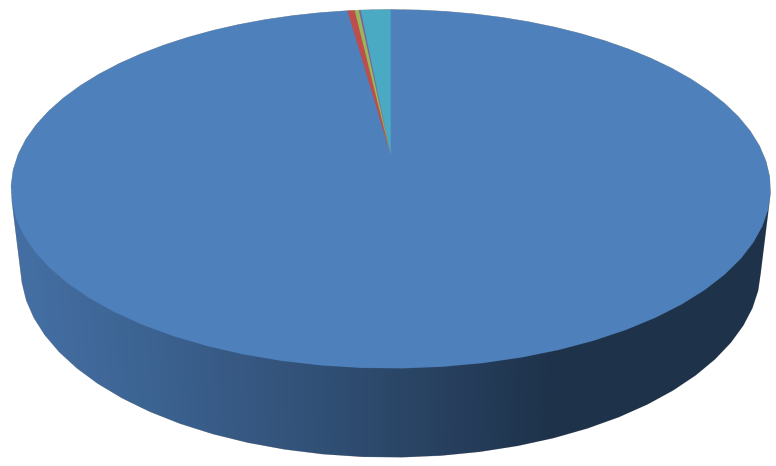

$\square$ School $\square$ College $\square$ Vocatioal institute $\quad$ Other Institue $\square$ Literacy Centre

Occupation Structure Of The Tribal People(In \%) In West Bengal, 1961-2011.

\begin{tabular}{|l|l|l|l|l}
\hline Occupation & 1961 & 1971 & 1981 & 2001 \\
\hline 1. Cultivator & 48.74 & 31.18 & 31.04 & 23.71 \\
\hline 2. Agricultural Labor & 28.39 & 48.91 & 48.73 & 45.09 \\
\hline $\begin{array}{l}\text { 3. Household Industry, } \\
\text { Manufacturing, Repairing }\end{array}$ & 1.34 & 1.02 & 1.05 & 2.2 \\
\hline 4. Other Services & 21.53 & 18.89 & 19.18 & 29.01 \\
\hline
\end{tabular}

Source: Census of India, West Bengal Series,1961- 2011, 


\section{OCCUPATION STRUCTURE OF THE TRIBAL PEOPLE OF WEST \\ BENGAL(IN \%), 1961-2011}

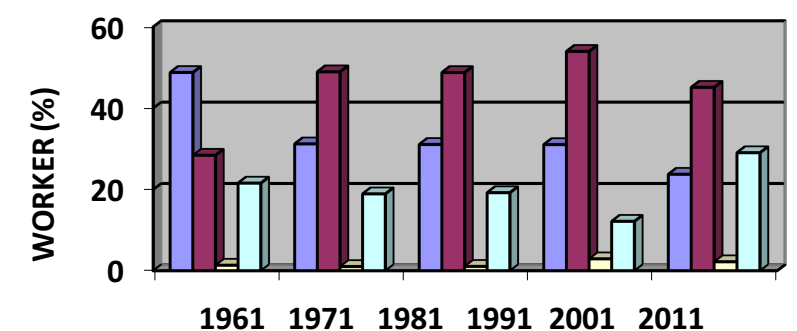

口Cultivator

口Agricultural Labor

DHousehold Industry, Manufacturing Repairing

DOther Services

For economic development some measures have taken by Ministry of Social Justice and Empowerment and Ministry of Tribal Welfare, Govt. of India. These are: a)Income Generation Scheme which include agriculture, horticulture, minor irrigation scheme, animal husbandry, social conservation of forest product, WADI etc. b)Job Oriented Scheme as manufacturing training, fashion sampling technology, tool room training and computer. By these programmes the tribal boys and girls got opportunity to introduced themselves with the modern technologies and economic world. They start to engaged in new job leaving their traditional activity. Some reservation scheme have taken for their education and job by govt. and some measures also taken for upgradation of tribal administration. As a result of this scheme occupational pattern have changed as the data shows (table-5). [7] More than 40per cent got job opportunity in different secand non govt. sector and in self business. On the other side due to industrialization process they are deprived more by losing their land. Because of this they engaged in work as agricultural labour for livelihood. As result of this percentage of agricultural labour is increased and percentage of cultivator is decreased. No of families benefitted through income generation and reservation of vacancy scheme for them. The improvement of economic life help to change their demographic behavior. As result of this some changes occur in demographic composition.

\section{Age Structure}

Age is an index of person's capacity, it is a significant measure of nation's vitality ( Chandna and Sidhu, 1980)8. The socio-economic structure, the supply of man power, the migration trend all these are influenced by age structure and age structure is closely related to birth, death marriage and the migration pattern and rate.

\section{Age Group}

Regarding age, the population is divided into three groups: i) young or adolescent (0-14 years); ii) adults (15-59 years); iii) the aged (60 and above years).The young are generally nonproductive and also non-reproductive. But this group is highly dependent. Social cost (9) is more but return is less. But in case of tribal people it is not applicable because children are engaged in earning money in this stage. The adult group is productive as well as reproductive with greater mobility rate. This group support the other two groups-the young and the aged. The percentage of aged people is inversely related to mortality rate. The aged group is controlled by mortality.[10] Percentage of female in aged group generally become higher than male but among the tribal people it not always happen. The age group is closely related to birth and death rate and migration which depend upon the development of any region. For instance if a country is urbanized and is equipped with infrastructural facilities, and had adequate job opportunities, the emigration rate will be low. At the same time better economic condition results in a low birth and death rate. But among the tribal people in this area changes of 
shifting of occupation from primary to secondary and tertiary sector is negligible. Because enhancement of education level is negligible. For this poor improvement in the literacy level engagement of worker in the primary sector is more. As result of this trend of changes in age composition is very low as the data (table-03 ) shows. Percentage of male and female are nearly equal among tribal and nontribal people. Percentage of young female population is more than nontribal people in both West Bengal (40) and Birbhum (41). In tribal society female are more active than male population they have more power in family than male members comparing to nontribal family as the table and diagram (no-03)shows. Female members are more active than male as the percentage of female marginal workers.

Table-6A \& 6B

Male And Female Of Tribal And Non-Tribal Population In Age Group (In \%) In West Bengal And Birbhum,1981.

Table (6A)

\begin{tabular}{|l|c|c|c|}
\hline WSET BENGAL & $0-14$ ( YEARS) & 15-59 (YEARS) & $\geq 60$ (YEARS) \\
\hline MALE, $(\mathrm{A})$ & 38 & 57 & 05 \\
\hline FEMALE(A) & 40 & 54 & 06 \\
\hline MALE (B) & 39 & 56 & 05 \\
\hline FEMALE (B) & 38 & 57 & 05 \\
\hline
\end{tabular}

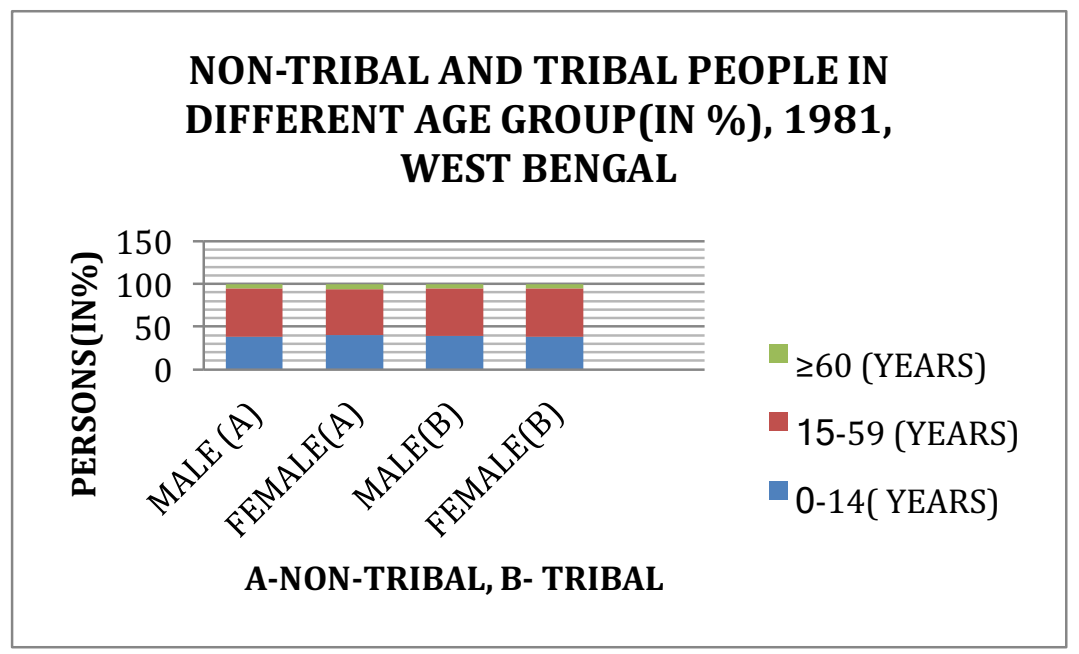

Table- 6B

\begin{tabular}{|l|c|c|c|}
\hline BIRBHUM & $0-14$ YEARS & 15-59 YEARS & $\geq 60$ YEARS \\
\hline MALE (A) & 40 & 56 & 04 \\
\hline FEMALE (A) & 41 & 54 & 06 \\
\hline MALE (B) & 38 & 58 & 04 \\
\hline FEMALE (B) & 37 & 58 & 05 \\
\hline
\end{tabular}




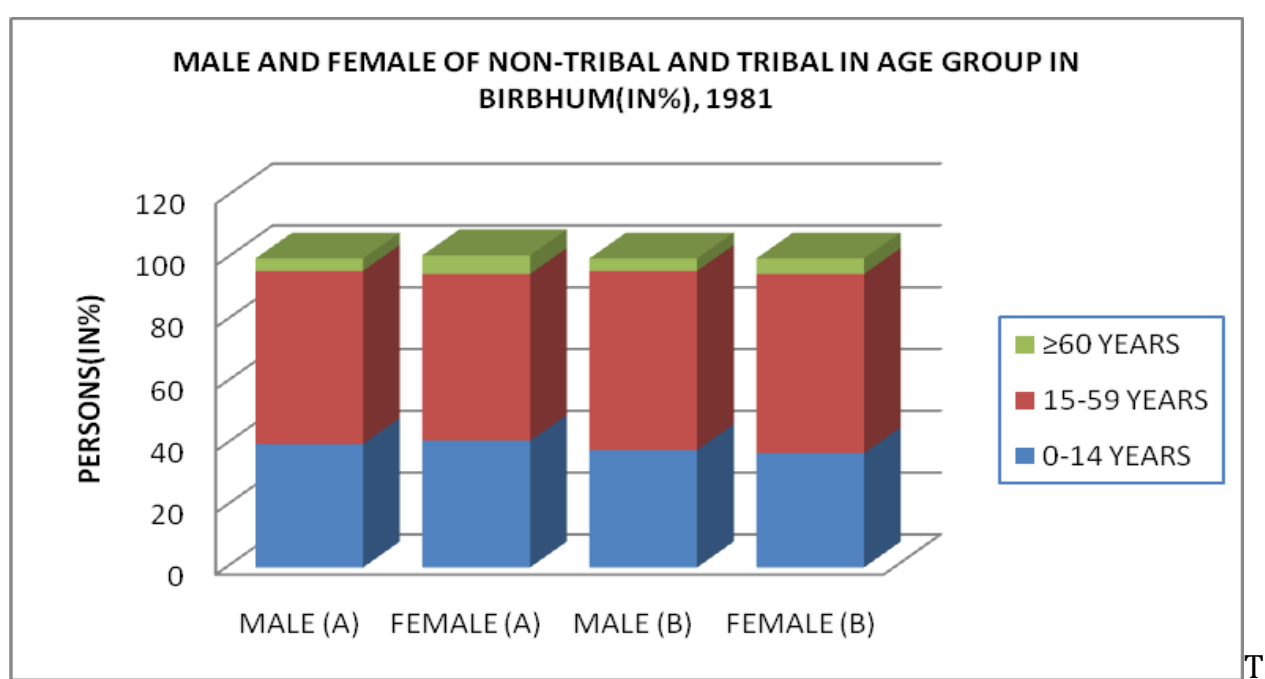

\begin{tabular}{|l|c|c|c|}
\hline BIRBHUM & $0-14$ YEARS & 15-59 YEARS & $\geq 60$ YEARS \\
\hline MALE (A) & 40 & 56 & 04 \\
\hline FEMALE (A) & 41 & 54 & 06 \\
\hline MALE (B) & 38 & 58 & 04 \\
\hline FEMALE (B) & 37 & 58 & 05 \\
\hline
\end{tabular}

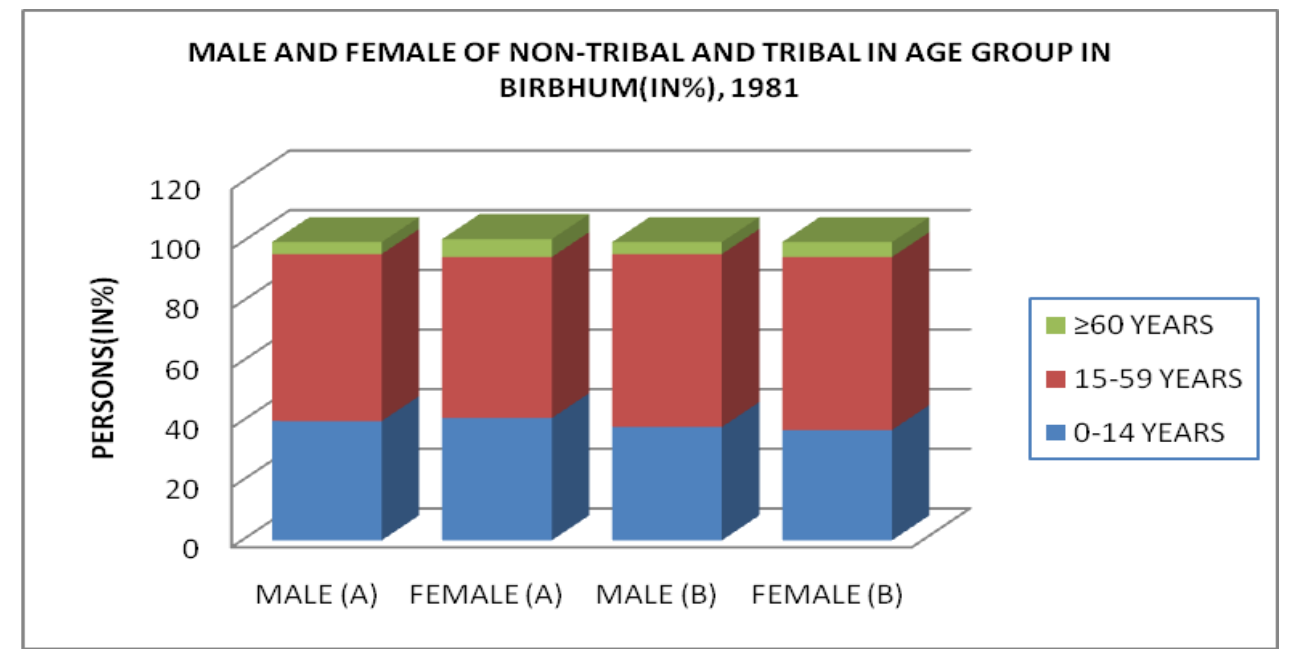

Table-07: Age Group Wise Tribal Population In Birbhum, 2011,** 2016

\begin{tabular}{|l|c|c|c|c|c|c|}
\hline & \multicolumn{3}{|c|}{2011} & \multicolumn{3}{c|}{$* * 2016$} \\
\hline & $0-14$ yrs & $15-59$ yrs & $\geq 60$ yrs & $0-14$ yrs & $15-59$ yrs & $\geq 60$ yrs \\
\hline MALE(\%) & 34 & 60 & 06 & 33 & 56 & 11 \\
\hline Female(\%) & 33 & 60 & 07 & 33 & 60 & 07 \\
\hline
\end{tabular}


MALE AMD FEMALE IN AGE GROUP(IN\%), BIRBHUM, 2011,2016

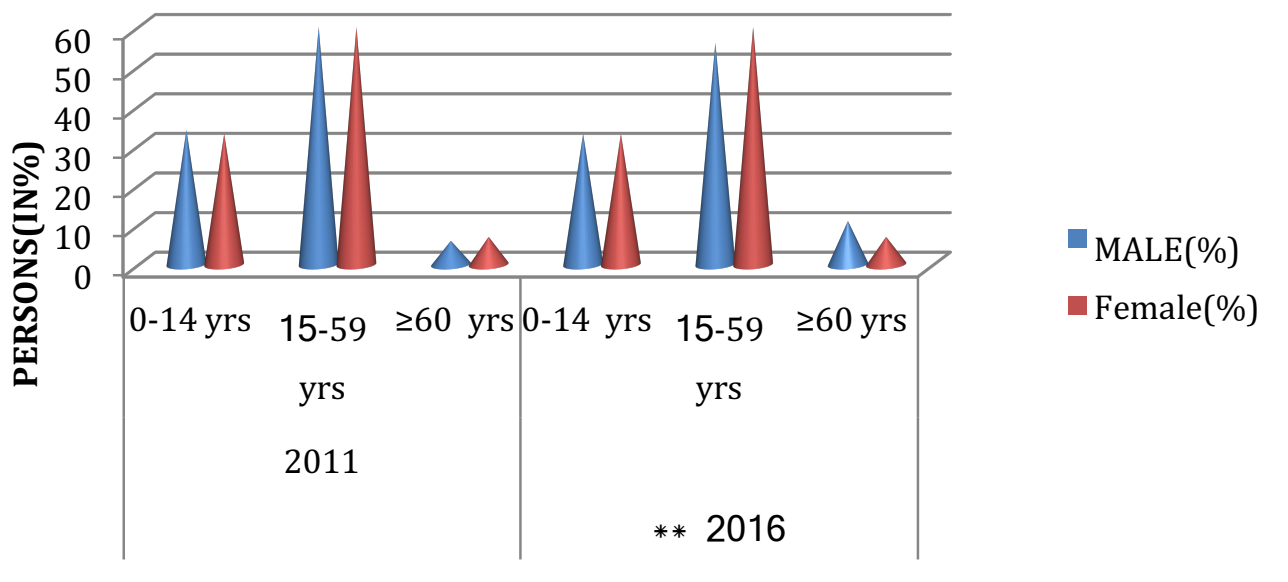

In the tribal or backward communities the young group is to some extent productive as well as reproductive. In many families a boy or a girl start to work at the age of 11 years as observed during field investigation. The female in this group has been found to get married at the age 1112 in some cases. Percentage of adult population is more. Percentage of old female population is more which shows that in spite of backwardness mortality is nearly equal to other caste people. Life expectancy rate among the male is less than female.

Dependency Ratio is another measure for studying the age structure. This ratio is measured by this formula-----

Dependency ratio $=\{[($ Young Population 0-14 (yrs) + Aged Population( $\geq$ yrs $)] /$ Adult Population(15-59yrs) $\} \times 1000$

The data (Table-05) shows that dependency ratio of the tribal and non-tribal population. The dependency ratio is among the tribal people is less than non-tribal people. Adult population is consider as the working population and this ratio shows

Table-08A

Dependency Ratio Among The Non- Tribal of West Bengal And Birbhum, 1981

\begin{tabular}{|c|c|}
\hline WEST BENGAL & BIRBHUM \\
\hline 801 & 805 \\
\hline
\end{tabular}

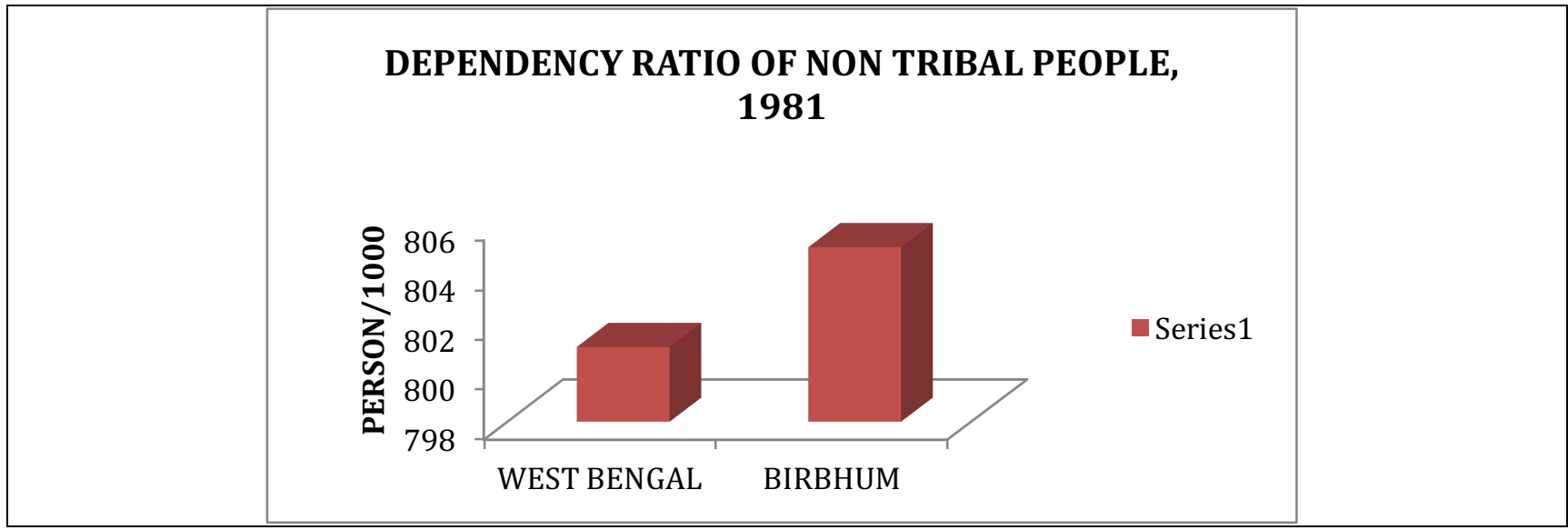


Table-08B

Dependency Ratio Among Tribal In West Bengal And Birbhum, $1981,2011 \& * 2016$

\begin{tabular}{|l|c|c|c|c|c|}
\hline CASTE & \multicolumn{2}{|c|}{1981} & \multicolumn{2}{c|}{2011} & ${ }^{* *} 2016$ \\
\hline & West Bengal & Birbhum & West Bengal & Birbhum & \multirow{2}{*}{ Birbhum } \\
\hline Tribal & 767 & 727 & 596 & 674 & 741 \\
\hline
\end{tabular}

Source: Census Data of 1981 and $2011,{ }^{* *}$ Field investigation

the number of dependants per thousand working population .But the dependency ratio can not give an accurate picture because all the adult persons are not working in

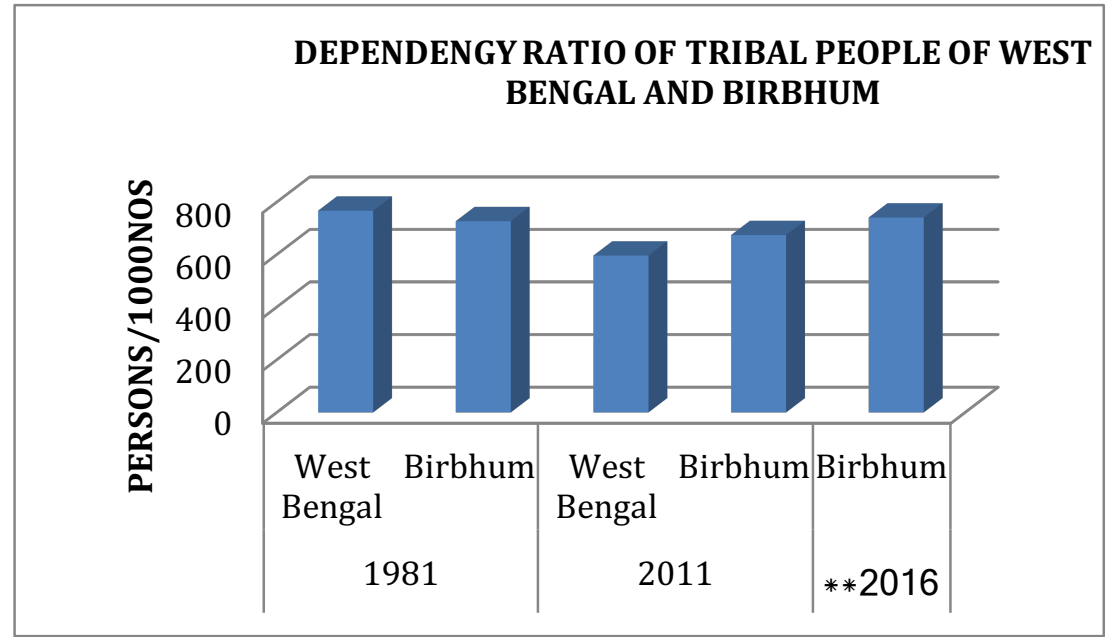

one hand and on the other in the young and adult people are not dependent in both group specially among those who are socio-economically poor and backward. Under certain circumstances the boys and girls from 11 or 12 years the young and the people above 60 years are engage in some light work to earn money. The ratio is higher among the non-tribal people than tribal people as the primary data is concern.

The birth and death rate and the death rate are related with dependency burden. High birth rate and low mortality rate increase dependency burden.

\section{Age-Sex Composition}

In age pyramid, age is graduated vertically at the interval of five years. The percentage of the female is plotted on the right hand side and male are on left hand side. This Age-Sex Pyramid give detail composite result of fertility, mortality, and migration of this backward community. Age -sex pyramid of any country or any region is the reflection of the development .Socioeconomic condition. In Birbhum district and west Bengal child population among male child is more than female reveals that death of female child is more than male which is the sign of underdevelopment. Migration among the male is more than female as the age-sex composition is concern. 
Table-09

Age- Sex Composition Of Tribal Community Of West Bengal

And Birbhumin (\%), 2011, **2016

\begin{tabular}{|c|c|c|c|c|c|c|}
\hline \multirow[t]{2}{*}{$\begin{array}{l}\text { AGE } \\
\text { GROUP(YRS) }\end{array}$} & \multicolumn{2}{|c|}{$\begin{array}{l}\text { WEST BENGAL } \\
\text { (2011) }\end{array}$} & \multicolumn{2}{|c|}{ BIRBHUM (2011) } & \multicolumn{2}{|c|}{ BIRBHUM **2016 } \\
\hline & MALE & FEMALE & MALE & FEMALE & MALE & FEMALE \\
\hline $0-04$ & 09.1 & 08.92 & 10.12 & 09.99 & 11.92 & 07.94 \\
\hline 05-09 & 10.49 & 10.21 & 12.16 & 11.49 & 10.22 & 07.94 \\
\hline $10-14$ & 11.25 & 10.82 & 12.06 & 11.25 & 10.95 & 06.35 \\
\hline $15-19$ & 10.86 & 10.20 & 10.08 & 09.43 & 10.71 & 11.64 \\
\hline $20-24$ & 09.65 & 10.17 & 09.01 & 09.79 & 07.79 & 10.32 \\
\hline $25-29$ & 08.76 & 08.80 & 08.51 & 08.52 & 06.68 & 10.32 \\
\hline $30-34$ & 06.91 & 07.03 & 06.98 & 06.92 & 06.57 & 09.26 \\
\hline $35-39$ & 06.95 & 07.37 & 06.58 & 06.81 & 07.54 & 07.94 \\
\hline $40-44$ & 06.36 & 06.34 & 05.96 & 05.70 & 05.84 & 04.76 \\
\hline $45-49$ & 05.49 & 05.40 & 05.02 & 05.11 & 04.62 & 05.82 \\
\hline $50-54$ & 04.40 & 04.10 & 04.13 & 04.10 & 03.89 & 04.50 \\
\hline $55-59$ & 03.16 & 03.18 & 03.04 & 03.42 & 02.68 & 05.29 \\
\hline $60-64$ & 02.74 & 02.95 & 03.13 & 03.53 & 03.89 & 03.44 \\
\hline $65-69$ & 01.70 & 01.94 & 01.66 & 02.01 & 04.87 & 02.91 \\
\hline $70-74$ & 01.07 & 01.27 & 0.87 & 1.10 & 0.97 & 0 \\
\hline $75-79$ & 0.48 & 0.58 & 0.29 & 0.41 & 0.49 & 01.06 \\
\hline $80+$ & 0.55 & 0.65 & 0.33 & 0.39 & 0.24 & 0.53 \\
\hline Age not stated & 0.09 & 0.08 & 0.04 & 0.04 & Nil & Nil \\
\hline
\end{tabular}

Source: Census Of West Bengal And Birbhum, 2011/** Field Investigation

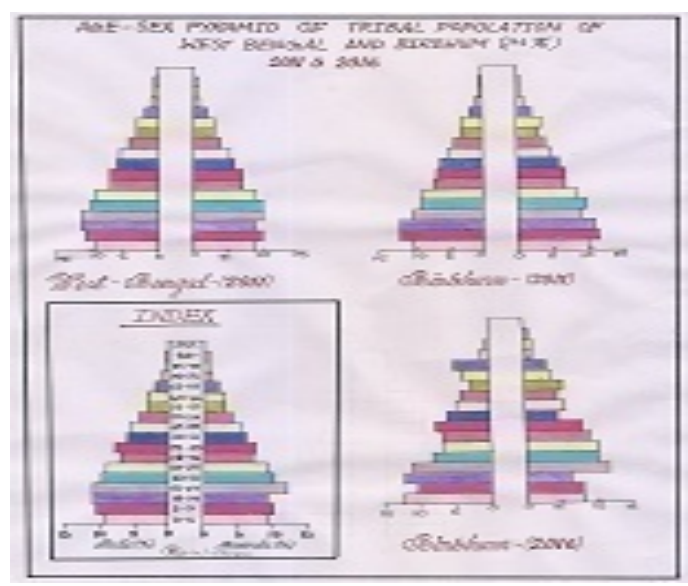

This data reveal that birth rate is higher than death rate among the tribal people in this region. As result of this upto the age group of 15-19 percentage of male and female are more than other group of population. Infant and Child mortality is less among this community. After that female population is increasing because of in-migration mainly due to marriage in the lower age group upto the age group of 25-29. On other side because of outward migration for occupation percentage of male population is decreasing. Females are biologically strong than male in one hand and secondly among the couple male member are senior to female member. Mortality rate among the male are more than female above 60 years as the data shows. 


\section{Sex Composition}

The number of two sexes is not important but the different role between them and the socioeconomic condition make an interesting point make an interesting point for the geographers (Clarke, 1969) .10 Sex composition is expressed by Sex Ratio. Sex ratio is measure by this formula; -

\section{Sex Ratio $=($ Number of females $/$ Number of Male $) \times \mathbf{1 0 0 0}$}

If the number of females is lower than male then the sex ratio will be lower or vice-versa. The female infant mortality is lower among the tribal people than non-tribal people which increase the sex ratio among the tribal people as the shows (table- 09). Increase in sex ratio mean the socio-cultural development of the tribal community. Preference of male child is decreasing. But the trend is same among the tribal and non tribal people.

Table-10(A)

Sex Ratio Of Non-Tribal And Tribal People In West Bengal And Birbhum, 1981, 2011.

\begin{tabular}{|l|c|c|c|c|}
\hline & \multicolumn{2}{|c|}{ WEST BENGAL } & \multicolumn{2}{c|}{ BIRRBHUM } \\
\hline Tribal & 1981 & 2011 & 1981 & 2011 \\
\hline NON-TRIBAL & 908 & 947 & 969 & 947 \\
\hline
\end{tabular}

\section{SEX RATIO AMONG NON-TRIBAL AND TRIBAL IN 1981 AND 2011}

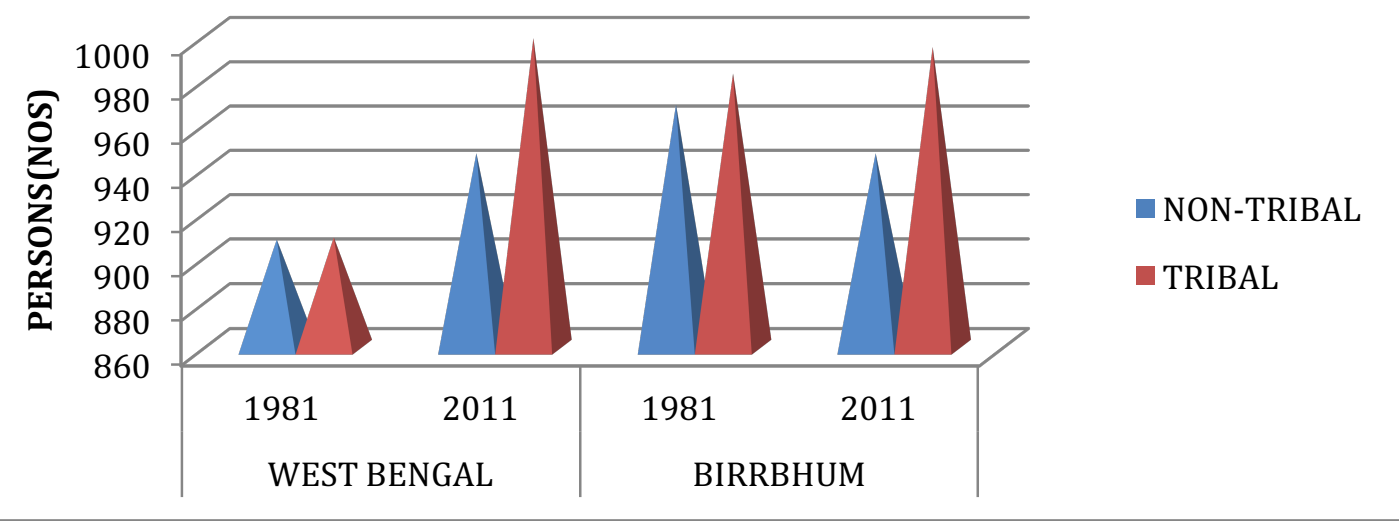

Sex Ratio Of Non-Tribal And Tribal People In West Bengal And Birbhum, 1981, 2011.

\begin{tabular}{|l|c|c|c|c|}
\hline & \multicolumn{2}{|c|}{ WEST BENGAL } & \multicolumn{2}{c|}{ BIRRBHUM } \\
\hline & 1981 & 2011 & 1981 & 2011 \\
\hline NON-TRIBAL & 908 & 947 & 969 & 947 \\
\hline TRIBAL & 909 & 999 & 983 & 995 \\
\hline
\end{tabular}

Source: Census Of India, West Bengal Series; 1981, 2011 


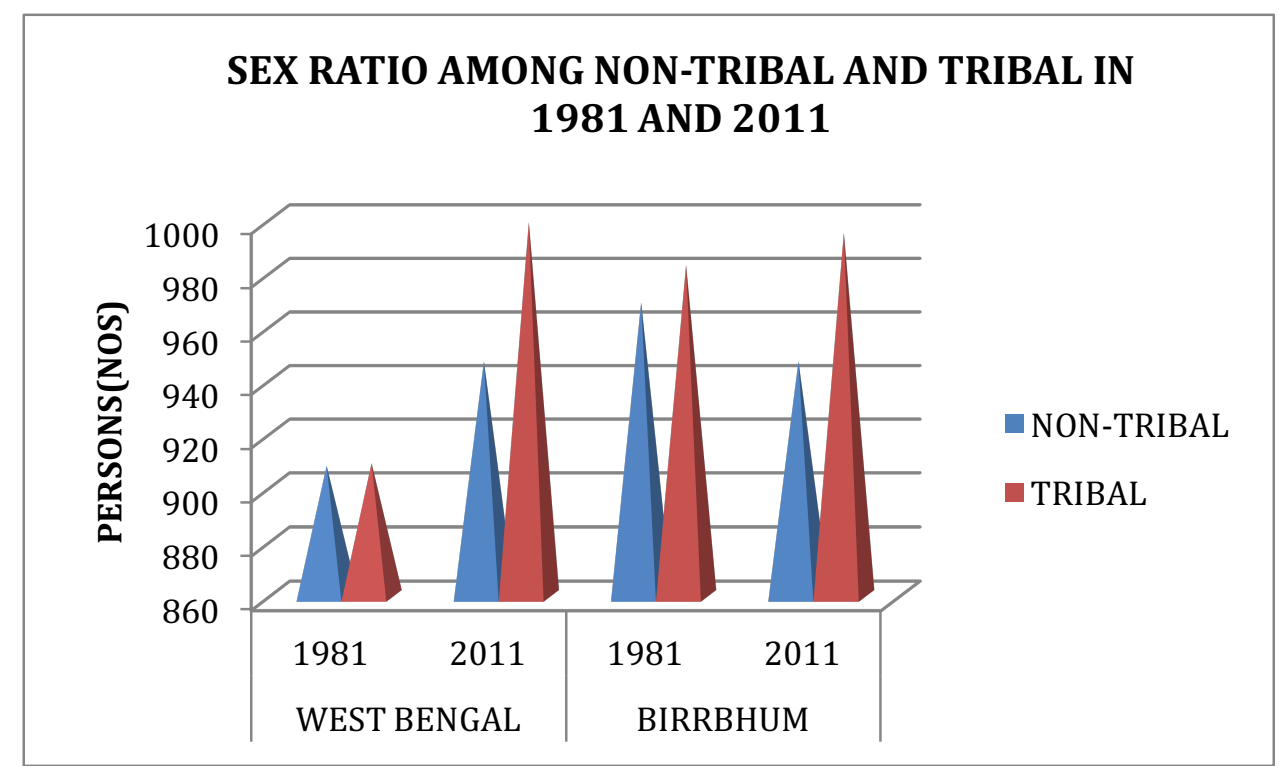

Table-10(B)

Trend Of Sex Ratio Of Tribal People Of Birbhum, 1961 - *2016

\begin{tabular}{|l|l|l|l|l|l|l|}
\hline 1961 & 1971 & 1981 & 1991 & 2001 & 2011 & $* 2016$ \\
\hline 902 & 923 & 956 & 982 & 992 & 1024 & 920 \\
\hline
\end{tabular}

TREND OF SEX RATIO OF TRIBAL POPULATION IN BIRBHUM ,1961-2016

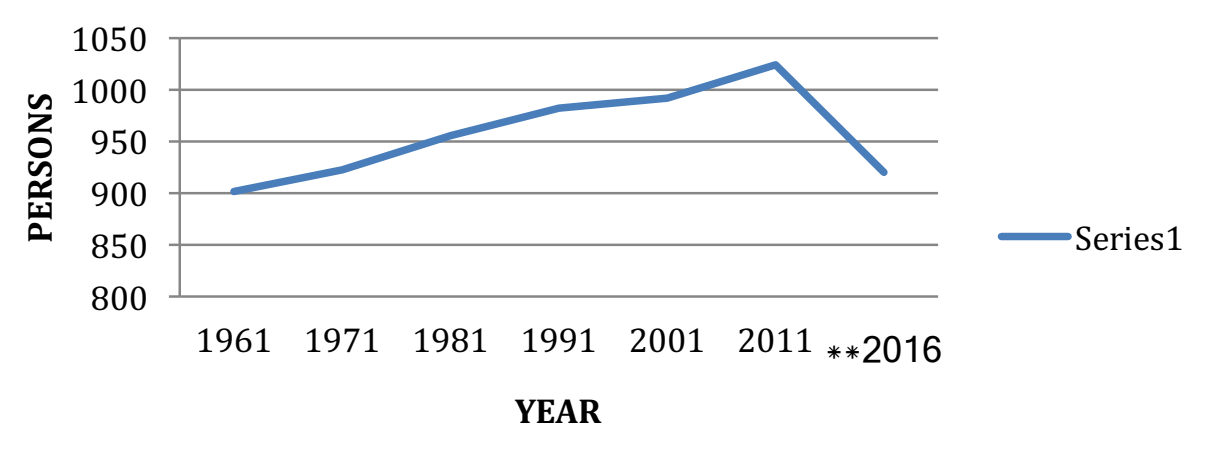

Source: Census of India, Birbhum District: 1961, 1971,1981, 2001, 2011 \& Field investigation, *2016.

The sex composition is mostly influenced by some demographic factors as birth and death rate, migration, marriage, preference of male children. But among the tribal community female child was equally important like male child because during marriage female get dowry so the sex ratio is gradually increasing as the diagram shows. But in recent period because of acculturation and impact of development programme about education and job their lifestyle and culture have transformed. Now the dowry system like other community have introduced. In Birbhum among tribal family position of female in a family is better than non-tribal family in rural area because women in tribal society are hard worker than male member, most of them are engaged in any type of work they get. On the other hand male member are comparatively lazy than women and they have a habit of taking drink . 


\section{Marital Status}

Demographic composition includes the distribution of population according to their marital status. Marital status of population means the proportion of single, married, widowed, divorced or separated male and female population. It is an important thing to study because in any society male and female enter into sexual life after marriage. Marriage is the first step of family formation. It is also important factor in fertility behaviour. It varies with the community.

Table-11

Marital Status Of The Tribal People In Birbhum (In \%), 1961, 1981

\begin{tabular}{|c|c|c|c|c|}
\hline & NOT MARRIED & MARRIED & WIDOWED & $\begin{array}{c}\text { DIVORCED \& } \\
\text { SEPARATED }\end{array}$ \\
\hline $1961(\mathrm{M})$ & 47.76 & 46.79 & 4.22 & 1.13 \\
\hline $1961(\mathrm{~F})$ & 43.31 & 44.80 & 11.48 & 1.71 \\
\hline $1981(\mathrm{M})$ & 52.60 & 43.09 & 3.05 & 1.24 \\
\hline $1981(\mathrm{~F})$ & 44.12 & 44.50 & 8.85 & 0.24 \\
\hline $2011(\mathrm{M})$ & 50.93 & 46.17 & 2.22 & 0.65 \\
\hline $2011(\mathrm{~F})$ & 41.56 & 45.93 & 10.49 & 0.95 \\
\hline
\end{tabular}

Source : Census of India, Birbhum District, 1961, 1981, 2011

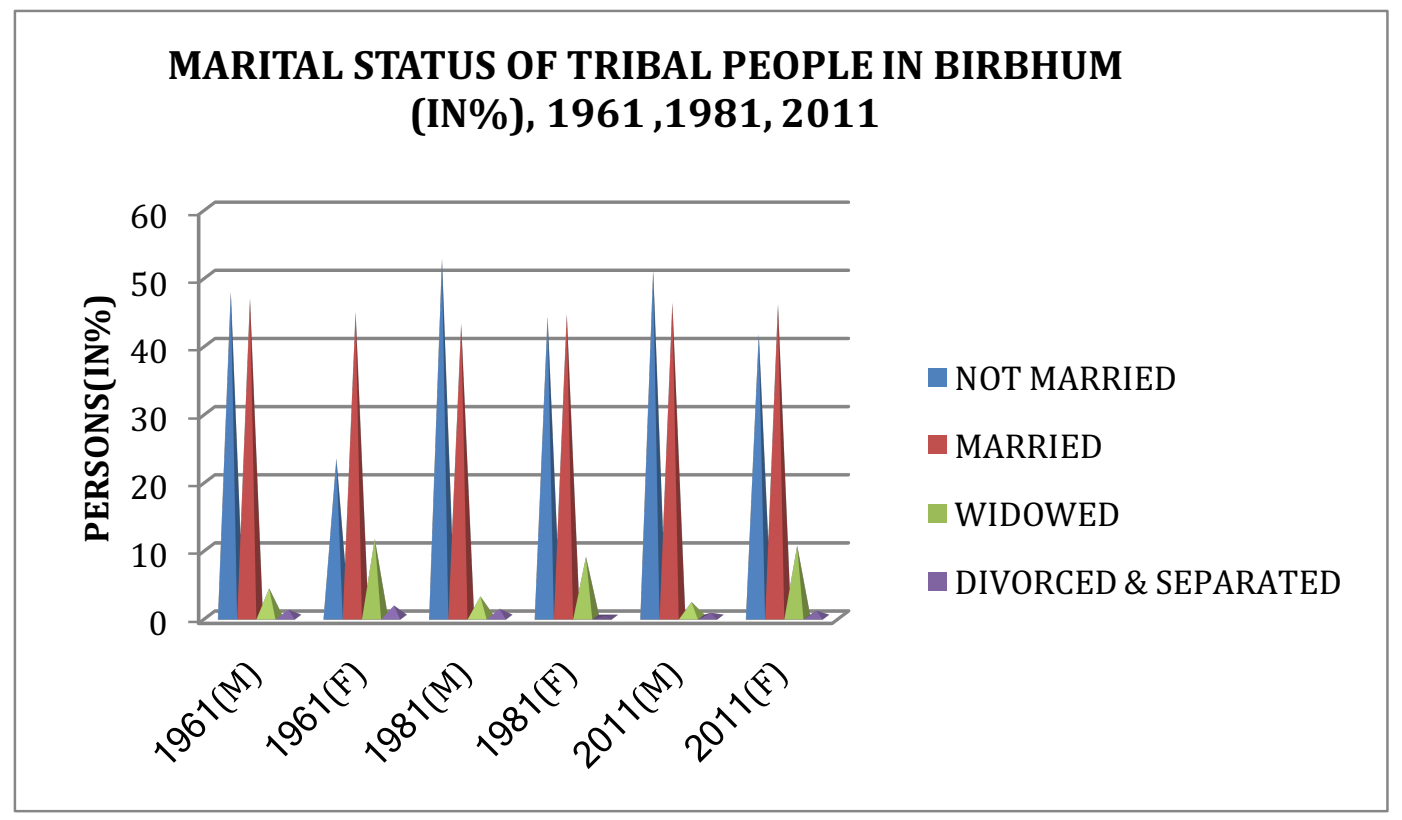

The data reveals that percentage of not married male and female is 47.16 and 43 and 43.31 in 1961 and it increased in 1981 but it decreased in 2011. But the percentage of married male and female is increasing from 1961 to 2011. But in case of widowed, divorced and separated male and female the trend is opposite. Because of improvement of socio-economic condition, acculturation and the improvement of educational status through the non-formal and formal education transformation of traditional thinking and lifestyle have changed. 


\section{FINDINGS}

The tribal people are characterised by their inherited dialect and socio-economic practices.After Independence govt have proposed to formulate National Policy on tribal people to bring them into the mainstream through some measures by which all round development will be possible. In the post independence period the then prime minister Pandit Nehru was very much in favour of integration of the tribal people in the constitution. For which he laid down the Dahbar Commission in 1960.The female literacy is an important indicator of social development. According to Sachchidananda education is an integral part of culture and it cannot be separated or divorced from the society they live in. But the tribal people do not believe in formal education. The transformation of tribal livelihood is mainly occurred by acculturation or cultural diffusion from other community.[14]Among which policy for improvement of education is important for socio-economic development and empowerment of tribal people. In taking this policy for reservation of seat in higher education level have taken. For betterment of socio-economic life reservation policy have taken in Govt services. In case of reservation policy the five principles of Prime Minister Jawaharlal Nehru known as' NEHRUVIAN PANCHASHEEL'S spelt out in 1952 have guided the administration of tribal affairs in taking policy. Formal education is the key of all round development of a human being. In spite of taking measure for their educational development percentage of literacy is not upto the standard because of some problems. Alienation from the society, lack of adequate infrastructure like school, hostels and teacher, abject poverty and irrelevant curricula are the main causes of poor literacy level. The tribal people are most hard working (specially the women), adaptive and simple in nature. For this some changes occur in their socio-economic, demographic and cultural aspect through acculturation. Informal Education plays an important role in changing their socio-economic, demographic and cultural life. The transformation of socio-cultural life among the people who are coexisted with other caste people is more than those people who live in isolated place.

If the policy taken for the betterment of their lifestyle and culture more attention have to be given to the problems they are facing in their life. More emphasis is needed on the availability of school with proper infrastructure and curricula and also the medium of learning and the no of teacher. Improvement in communication network is the most important thing to grow awareness among them about the programmes implemented for the betterment of their lifestyle. If their literacy level is improved their economic, socio-cultural and demographic pattern also changed.

\section{Note And References:}

Bhupinder Singh (1989) in M M Raha and Palash Chandra Coomer( Ed.)TRIBAL INDIA; Problem Development Prospect, Gian Publishing HouseN.Delhi-2, p. no 01-07.

Claeke, John I. (1969)Population Geography, Pergaman Press, Oxford, p.no.62.

D.Basu (1995) Introduction To The Constitution of India; Prentice Hall of India Pvt. Ltd., New Delhi; p.n. 07

Trewartha, Glen I.(1969); Geography of Population: World Pattern; John Wiley \& Sons ,Inc p114-115.

D.D.Basu (1995) Introduction to The Constitution of India; Prentice Hall of India Pvt. Ltd., New Delhi; p.n.16-20 Ghosh Prasasti (1993) Phd. Thesis (unpublish) p.n.38--39.

Ghosh Prasasti (2016) Impact of Globalization on Tribal World of West Bengal,vol:20 Issue-7, -p29-36.

Chandna R.C. and Manjit S. Sidhu (1980); Introduction Of Population Geography, Kalyani Publishers,New Delhi; p .n.86.

Social Cost : The cost incurred for food, cloth, medicine and others to bringing up the children.

Same as no 2 p.n.79-80.

Panchasheal: 
Ghosh, P. (2018). Development of Education and Its Impact on The Population Composition of The Tribal People of Birbhum District of West Bengal. Advances in Social Sciences Research Journal, 5(1) 64-82.

- Development should be according to their own genius ;

- Tribals' right on Land and Forest should be respected;

- Training about administrative and Development have to given to the Tribal team by which they can inducted in Committee;

- Tribal Development Programmes should be undertaken without disturbing their social and cultural institution;

- The Tribal Development Index should be based on quality of life not the amount of the grant.

D .D.Basu (1995) Introduction to The Constitution of India; Prentice Hall of India Pvt. Ltd., New Delhi; p.n.16.

Census of India; West Bengal Series, Special Table on Scheduled Castes and Scheduled Tribes ; Govt of India. 1961, 1971, 1981, 1991, 2001, 2011.

Sachidananda(2012) Tribal Education. Implication for development, Concept Publishing Company ,N delhi. P253255. 